\title{
田
}

\section{EDUCAÇÃO SUPERIOR E DESENVOLVIMENTO SOCIAL NO ESTADO DA BAHIA: UM ESTUDO SOBRE AS UNIVERSIDADES ESTADUAIS BAIANAS}

Higher education and social development in the Bahia's state:

a study on the state universities

\section{Patricia Lessa Santos Costa'}

\section{RESUMO}

Este trabalho analisa a temática da ação participativa no âmbito da cultura cívica. O objeto empírico eleito para o estudo é o processo histórico de criação e consolidação das quatro universidades estaduais da Bahia (Uneb, Uefs, Uesc e Uesb), a partir da década de 60, como expressão de setores da sociedade civil, em diversas regiões, pela conquista do direito à educação universitária. O pressuposto mais geral orientador do trabalho é de que o desenvolvimento de uma sociedade depende de que os indivíduos se orientem coletivamente em torno de princípios e valores, expressos a partir da formação das identidades coletivas, com vistas a alcançar direitos e condições de reprodução de vida, favorecendo, assim, o desenvolvimento de uma vida sociopolítica democrática. Esse tipo de ação se contrapõe à tradição brasileira em que a emergência de uma cultura cívica pluralista tem sido dificultada por uma sociedade elitista e segmentada em torno de desigualdades diversas, seja no acesso às agências públicas, seja com relação à própria integridade do

${ }^{1}$ Doutora em Ciências Sociais pela Universidade Federal da Bahia. Professora do Departamento de Educação da Universidade do Estado da Bahia, Área: Sociologia. E-mail: <plessacosta@gmail.com>. 
cidadão (fome, segurança, saneamento, infraestrutura urbana e rural, etc.), seja pelo não reconhecimento dessas desigualdades que inferiorizam e também das diferenças. Trata-se de uma pesquisa qualitativa, que englobou o levantamento e a análise de conteúdo de informações oriundas de entrevistas com os atores que protagonizaram tal empreendimento, bem como de documentos. $O$ estudo revela a visão que esses indivíduos têm desse processo e como avaliam a universidade que ajudaram a edificar, produto do seu protagonismo. No caso das quatro universidades baianas, que apresentam perfis e processos históricos diferenciados, a criação remonta à trajetória nacional de incentivo à formação de professores para o ensino médio e de profissionais para a indústria crescente, trajetória essa iniciada na década de 50 e consolidada nas décadas seguintes. No bojo do período desenvolvimentista, ganhou impulso o processo de luta por um reconhecimento das demandas regionais por educação, com vistas à inclusão cultural, por parte dos pioneiros dessa iniciativa nas várias regiões da Bahia. São intelectuais, educadores, políticos, líderes comunitários e religiosos que constituíram um movimento irradiador do desenvolvimento a partir da universidade.

\section{PALAVRAS-CHAVE}

Conhecimento. Moralidade. Solidariedade regional. Universidade. Sociedade civil. Reconhecimento. Capital social.

\section{ABSTRACT}

This study examines the theme of participatory action in the civic culture. The empirical object of study is elected to the historical process of creation and consolidation of four state universities of Bahia (Uneb, Uefs, and Uesc Uesb) from the 6o's as an expression of civil society sectors in various regions, by winning the right to university education. The most general assumption guiding the study is that the development of a society depends on the individuals who collectively are geared around principles and values, expressed through the formation of collective identities, in order to achieve reproductive rights and conditions of 
life, thus favoring the development of a democratic socio-political life. This kind of action goes against the Brazilian tradition in which the emergence of a pluralistic civic culture has been hampered by an elitist society and targeted around various inequalities, either in access to public agencies, as related to the very integrity of the citizen (hunger, safety, sanitation, urban and rural infrastructure, etc.) is not to recognize that these inequalities and also degrade the differences. This is a qualitative research, which included the survey and content analysis of information from interviews with the actors that played such an enterprise, as well as documents. The study reveals the view that these individuals are evaluating this process and how the university who helped build a product of their role. In the case of four universities from Bahia, featuring profiles and different historical processes, the creation dates back to the national trend to encourage the training of teachers for high schools and professionals for the growing industry, this trend started in the 50's and consolidated in the decades following. At the core of the developmental period, the process gained momentum in the fight for recognition of regional demands for education, aimed at cultural inclusion, by the pioneers of this initiative in the various regions of Bahia. They are intellectuals, educators, politicians, community and religious leaders who formed a movement of development radiating from the university.

\section{KEYWORDS}

Knowledge. Morality. Regional solidarity. University. Civil society. Recognition. Social capital.

\section{BREVE RELATO SOBRE O ENSINO SUPERIOR NO BRASIL}

Muitos estudiosos da história da universidade no Brasil entendem que sua instalação no país se deu tardiamente. Enquanto em países da América espanhola as primeiras escolas superiores foram fundadas no século XVI, no Brasil, só em 1808, com a chegada da família real à colônia, foi fundado o Colégio Médico-Cirúrgico da 
Bahia, tendo em vista as condições de saúde precárias da colônia. Sobre os motivos desse atraso, Carneiro infere:

A ciência no Brasil colonial se viu ainda mais atrasada em relação ao resto da América Latina devido à sobrevivência em Portugal do escolasticismo até as reformas pombalinas da segunda metade do XVIII. Diferentemente da Espanha, que criou universidades, promoveu oficialmente estudos sobre as grandes civilizações (astecas: Sahagun; maias: Diego de Lando; e incas: Bernabé Cobo), e sobre os recursos naturais (Relaciones Geográficas entre 1577 e 1586), além de permitir expedições como a de La Condamine, em 1736, a coroa portuguesa vetou a divulgação de informações e as viagens para a sua maior colônia, escondida do mundo até a vinda da família real em 1808, quando tornou-se o foco de interesse dos naturalistas do século XIX (CARNEIRO, 2002, p. 3).

Já no começo da República, no final do século XIX, o Brasil era considerado o "[...] lugar mais insalubre do mundo [...]", e a medicina, juntamente com a advocacia e a engenharia, eram as únicas profissões universitárias do país, sendo o baixo desenvolvimento industrial o fator que limitava a demanda por profissões técnicas. Caso excepcional no campo da ciência foi a invenção do avião por Santos Dumont, em 1906 (CARNEIRO, 2002, p. 4).

Somente em 1920, com o Decreto $n^{\circ} 14.343$, é criada a primeira instituição universitária no País, a Universidade do Rio de Janeiro, com reitor nomeado pelo presidente Epitácio Pessoa. No mesmo ano, forma-se a Universidade do Brasil, na capital federal. Também foram criados o Instituto Brasileiro de Geografia e Estatística (IBGE) e a Universidade de São Paulo (USP), em 1934. Esta universidade resultou de uma agregação de escolas superiores e contou com a influência de uma elite de intelectuais e educadores com inserção política suficiente para influenciar o governo (FÁVERO, 1988).

A intensificação das discussões sobre a educação superior no Brasil remete ao período de transformações econômicas decorrentes da industrialização e urbanização a partir da década de 30. É no período do Estado Novo que se começa a delinear um planejamento nacional da educação em todos os seus níveis, com a criação de importantes instâncias governamentais, 
como o Ministério da Educação e Saúde (em 1930). Também os Decretos de Francisco Campos² dão maior organicidade ao ensino médio. Em 1931, institui-se o Estatuto das Universidades Brasileiras, pelo Decreto Federal n 19.851, de 1931. Também é criada, em 1937, a União Nacional dos Estudantes (UNE), que defendia, no campo político, o fim da ditadura do Estado Novo e, no campo educacional, a universidade para todos e a sua autonomia frente ao estado.

Na década de 30, vários movimentos políticos com posições ideológicas divergentes - os liberais, que reivindicavam um país com base urbano-industrial e uma universidade ligada às mudanças; os conservadores da Igreja Católica, que defendiam o ensino privado; e o movimento das classes populares pela popularização do ensino superior - reivindicavam reformas na educação do Brasil. Desse processo resultaram as propostas educacionais consolidadas na Constituição de 1934 e no Plano Nacional de Educação (PNE). Em 1937, com o Estado Novo e a implantação de políticas voltadas para a formação de elites dirigentes e profissionais liberais, a universidade tornou-se altamente seletiva, excluindo desse nível de educação amplos contingentes da população (MIDLEJ, 2004).

De acordo com Cunha (1988), com o fim do Estado Novo e a Constituição de 1946, que reflete o processo de democratização do país a partir da garantia de direitos, não houve uma mudança muito significativa na forma como se organizava a educação nacional. O ensino médio era dividido em profissionalizante, voltado para as classes trabalhadoras, e científico (ou propedêutico, segundo terminologia da época), dirigido para as elites que iriam ingressar no ensino superior (CUNHA, 1988).

2 O Decreto Federal $n^{\circ} 19.890$, de 1931 dispõe sobre a organização do ensino secundário; o Decreto Federal $n^{\circ}$ 21.241, de 1932 consolida as disposições do anterior. De acordo com Piletti (1987) e Romanelli (1996), a reforma Francisco Campos conferiu maior complexidade a esse grau de ensino e proporcionou encaminhamentos mais específicos ao nível superior. Entre as medidas, houve o aumento da duração do curso secundário, que passou de cinco para sete anos, sendo dividido em dois ciclos: o fundamental, com um período de cinco anos, e o período secundário, com período de dois anos e tendo caráter formativo para o ingresso no ensino superior. Ainda de acordo com os autores, esse modelo novo era próximo daquele existente nos países desenvolvidos do Ocidente que, desde o fim do século XIX, modernizaram o ensino secundário, a partir do duplo ciclo. 
Em 1946, uma nova Constituição de caráter mais liberal deu início a um processo de formulação da Lei de Diretrizes e Bases da Educação (LDB), aprovada somente em 1961. Nessa década, e a partir da nova conjuntura política e ideológica, exigiu-se da universidade a modernização necessária ao novo contexto social desenvolvimentista. Dela cobravam-se, cada vez mais, a formação de mão de obra especializada para a indústria e a expansão da oferta, para atender à crescente demanda da classe média.

A expansão da infraestrutura produtiva brasileira permitiu, a partir dos debates políticos da época, a formulação do projeto nacional-desenvolvimentista nos anos 50. Com o retorno de Getúlio Vargas (1950-1954) à presidência da República, foram tomadas medidas que permitissem ou facilitassem a progressão para o ensino superior, medidas ${ }^{3}$ essas cristalizadas na Lei de Diretrizes e Bases de 1961 - Lei Federal 4.024, de 1961, que institui o Conselho Federal de Educação. Nesse período, já vinha ocorrendo uma expansão do ensino médio, e, por conseguinte, uma maior pressão para ingresso no ensino superior (CUNHA, 2007).

Dessa forma, pode-se afirmar que o período entre 1945 e 1960 consolidou um projeto de universidade nacional voltado para as questões democráticas e do desenvolvimento tecnológico emergente. Esse processo se deu em meio a muitos conflitos, próprios da sociedade brasileira, que passou de uma estrutura agrário-exportadora para uma urbano-industrial baseada na ideologia nacional-desenvolvimentista (TEIXEIRA, 1998).

De acordo com lanni (1996), no Brasil, a ideia de universidade esteve associada à de modernização pela via do desenvolvimento da ciência e tecnologia (IANNI, 1996). Aqui, o tema da universidade será discutido pari passu com o próprio desenvolvimento da ciência, ao qual a instituição está atrelada, e o processo de modernização do país (urbanização, industrialização).

A partir da década de 60, a grande expansão do ensino médio, com a consequente demanda pelo ensino superior, impôs no-

3 Uma dessas medidas pôs fim ao exame de admissão do primário para o ginásio, que continha a demanda nas séries iniciais. 
vos desafios em termos de educação ao estado nacional, forçando-o a adotar uma série de medidas no sentido de ampliar a oferta pública e particular desse nível de ensino (CUNHA, 2007). Nesse período, foram criadas novas faculdades federais; a gratuidade foi instituída, de fato, nessas instituições; e algumas faculdades estaduais e privadas foram federalizadas. Note-se, no entanto, que a ampliação da oferta de ensino público federal não se deu de forma balanceada em todo o território nacional, confirmando o entendimento de que o ensino superior público no Brasil teve sua expansão, por exemplo, fora da Bahia. No que tange às faculdades privadas, várias medidas formam tomadas no sentido do seu fomento (ROMANELLI, 1996; CUNHA, 2007).

\section{POLÍTICA DESENVOLVIMENTISTA E ENSINO SUPERIOR NA BAHIA: INTERIORIZAÇÃO A PARTIR DAS REGIÕES MAIS PROEMINENTES}

O processo de expansão do ensino superior na Bahia ganha nova dinâmica a partir das transformações estruturais ocorridas no Brasil na década de 60, que possibilitaram a autorização de faculdades isoladas pelo interior dos estados (MIDLEJ, 2004). De acordo com Lima (2008), a gênese da educação pública no âmbito estadual tem como marco o ano de 1967, quando o governo Luiz Viana Filho instituiu um Departamento de Educação Superior (Lei $\mathrm{n}^{\circ} 2.454$, de 1967), coadunando-se com o cenário nacional desenvolvimentista de fomento à formação de quadros para o novo cenário nacional. A citada lei previa a realização de estudos para o desenvolvimento da educação superior como mote para o crescimento econômico do estado. Alia-se, pois, a educação superior ao desenvolvimento econômico, o que, para Lima, fere a autonomia da universidade estadual nascente.

O autor ainda estabelece uma diferenciação entre o quadro de expansão do ensino superior na Bahia e o de estados do Sul e Sudeste, que se organizaram com a inserção das universidades federais e também de estabelecimentos privados. A Bahia não se articulou com o governo federal pleiteando universidades federais. Por quê? Essa questão paira no ar, assim como os 
possíveis entendimentos ou explicações que a classificam de singularidade baiana ${ }^{4}$.

Cunha, ao referir-se a esse aspecto como 'singularidade do caso baiano', afirma ser essa expansão, [...] uma peculiaridade da educação superior brasileira [...] que se refere à ampliação da rede privada, não se efetiva na Bahia com a intensidade verificada em nível nacional. E, em lugar desta rede, vai surgir um novo setor que promoverá a singularidade do caso baiano, nesse período: o Governo Estadual será o ator que vai assumir, para si, o movimento de expansão e interiorização da educação superior [...], como um traço muito forte nas suas políticas, a partir daí até os dias atuais (CUNHA, 2002, p. 77 apud LIMA 2008, p. 59).

As discussões sobre a oferta estadual de ensino superior, iniciadas na década de 60 - fomentadas, em parte, pela criação de faculdades de iniciativa privada em Ilhéus e Itabuna -, intensificam-se nos anos 70 a partir da pressão das sociedades regionais, encabeçadas por indivíduos e grupos que se articulavam com o poder público.

Em fins da década de 50 e começo dos anos 60, começavam a surgir debates e iniciativas em torno do planejamento do desenvolvimento na Bahia, agregando instituições do governo e intelectuais, como Rômulo Almeida e Milton Santos. Este último assumiu a Comissão de Planejamento Econômico (CPE) do governo do estado baiano em 1963, no período do governador Lomanto Júnior (19631967), em que se intensificavam as reivindicações pela descentralização do poder, tendo em vista a sua centralização na capital (SILVA, 1996). Naquela época, inexistia uma visão ampla da realidade do estado que pudesse fundamentar uma política econômica. De acordo com Pedrão (1996), o papel de Milton Santos foi importante no sentido de dar respaldo ao governo Lomanto Júnior, frente aos quadros técnicos de planejamento e aos intelectuais baianos. Milton Santos realizou, nessa época, importantes estudos sobre as

4 Apenas muito recentemente foram implantadas duas novas universidades federais na Bahia, a Universidade Federal do Recôncavo Baiano (UFRB) e a Universidade Federal do Vale do São Francisco (Univasf), tendo em setembro de 2011 sido anunciada pela presidente da República, Dilma Rousseff, a criação de mais duas universidades federais na Bahia a serem implantadas em 2013. 
regiões da Bahia em torno do planejamento regional e enfatizou a importância de analisar o processo de urbanização e a consequente influência das cidades na estruturação do espaço. Isso o levou a considerar a necessidade de realizar uma divisão de regiões baseadas nas áreas de influência urbana das cidades que aglutinavam atividades econômicas. Foi assim que ele definiu a existência, por exemplo, de uma região cacaueira da Bahia - tema abordado em um de seus livros (SANTOS, 1959).

Em seu estudo A cidade como centro de região (SANTOS, 1959), o autor analisa a cidade como forma de organização do espaço, presidindo a organização de um espaço mais amplo, que forma a sua "[...] zona de influência [...]". A cidade - que hoje costuma ser chamada cidade-polo - teria como característica central um dinamismo capaz de influenciar as áreas do seu entorno.

Essa ênfase nas cidades-polo e em suas zonas de influência se coaduna com o objetivo de planejar o desenvolvimento a partir de uma regionalização que possibilitasse, inclusive, conhecer melhor os diversos espaços com vistas a fornecer ao Estado condições para exercer seu papel de agente indutor do desenvolvimento. Assim, para Santos (1959), o fator preponderante a ser observado no estudo do espaço é a sua organização a partir das cidades e de seus fatos humanos (atividades econômicas aglomeradas nesses centros, redes de transporte que ligam as cidades a seu entorno, dentre outros) e não dados físicos.

Mais do que locais de produção, para Santos (1959), as cidades são locais de sociabilidades, seja para a produção e circulação de mercadorias, seja para a circulação de cultura a partir das intensas relações que elas favorecem e que fazem circular experiências, valores, conhecimentos. Se, do ponto de vista econômico, as cidades mobilizam mercadorias, do ponto de vista social, mobilizam imaterialidades, capital social, humano e simbólico. É com base nesses aspectos que Silva (2003) explicita três sentidos clássicos das cidades, a saber: a urbe, expressão que se opõe a rus (de rural); a polis, pelo seu sentido político e administrativo; e a civitas, que diz respeito à sua complexidade, formada por instituições e grupos diversos.

Foi com o objetivo de compreender e administrar (e controlar) 
um estado com características tão diversas e com um território tão amplo ( $565.000 \mathrm{~km}^{2}$ ) que se empreenderam vários tipos de regionalizações, com base em fatores econômicos, educacionais, políticos. No ano de 1966, por exemplo, por meio da Lei Estadual $n^{\circ} 2.321 / 66$ e com o objetivo de descentralizar as ações das secretarias do estado, a Bahia foi dividida em 21 regiões administrativas, cada uma delas com subunidades de administração, localizadas em cidades-sede regionais (CAMPOS, 2000 apud DI LAURO, 2009). A Fig. 1 representa tal divisão, ainda hoje utilizada nas políticas de governo.

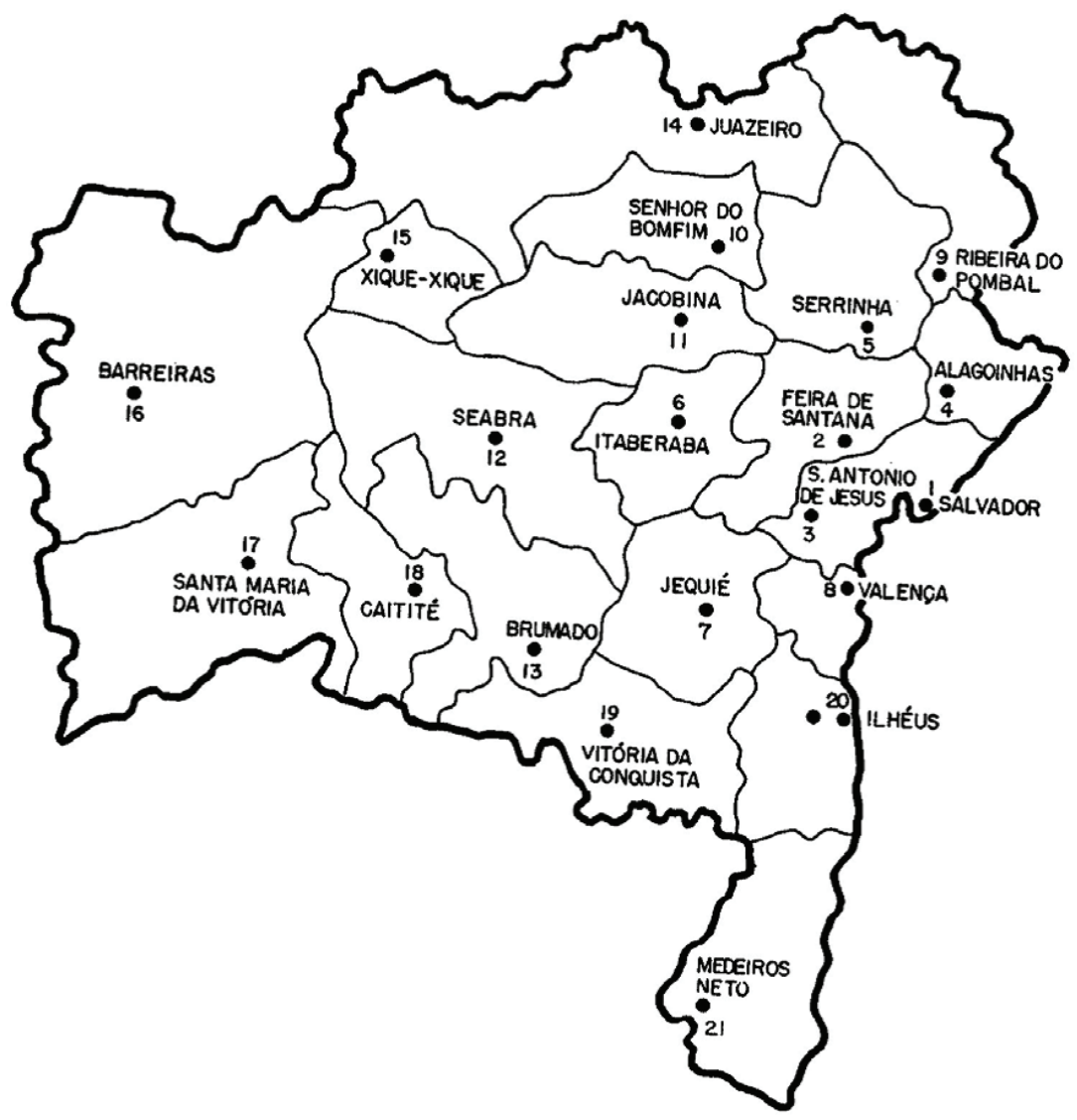

Figura 1 - Regiões Administrativas da Bahia, 1966.

Fonte: Superintendência de Estudos Econômicos e Sociais da Bahia (1973). 
Como se vê, a representação gráfica prioriza, nas regiões administrativas, as cidades mais relevantes. Não é por acaso que, nos dias de hoje, praticamente todas elas, à exceção de Medeiros Neto, Santa Maria da Vitória e Ribeira do Pombal, têm campi de universidade estadual.

Na década de 60, eram consideradas principais regiões urbanas, por Milton Santos, as cidades de Ilhéus e Itabuna, Feira de Santana, Jequié, Juazeiro, Vitória da Conquista, Alagoinhas, Senhor do Bonfim, Jacobina e Salvador (MIDLEJ, 2004). Assim, a decisão política de implantar o ensino superior considerou, em certa medida, uma espécie de hierarquia por grau de desenvolvimento das cidades. Essa opção refere-se à consideração, à época, de que uma universidade precisa ser instalada em um local que possibilite condições para sua sobrevivência, tais como infraestrutura urbana e de estradas que permitam o fluxo de pessoas, logística de transportes, demanda populacional advinda do ensino médio, demanda por qualificação profissional (dada pelo dinamismo da economia), isto é, uma série de fatores que foram considerados. Pode-se dizer que o ponto de partida foi o perfil apresentado a partir das regionalizações do estado. A interiorização do ensino superior seguiu o vetor da representatividade das cidades. A Uesb está presente em Vitória da Conquista, Itapetinga e Jequié; a Uesc, em Ilhéus e Itabuna; a Uefs, em Feira de Santana; a Uneb, inicialmente, em Salvador, Alagoinhas, Juazeiro, Caetité, Santo Antônio de Jesus e Jacobina. A Fig. 2 apresenta a localização geográfica das quatro universidades estaduais da Bahia. 


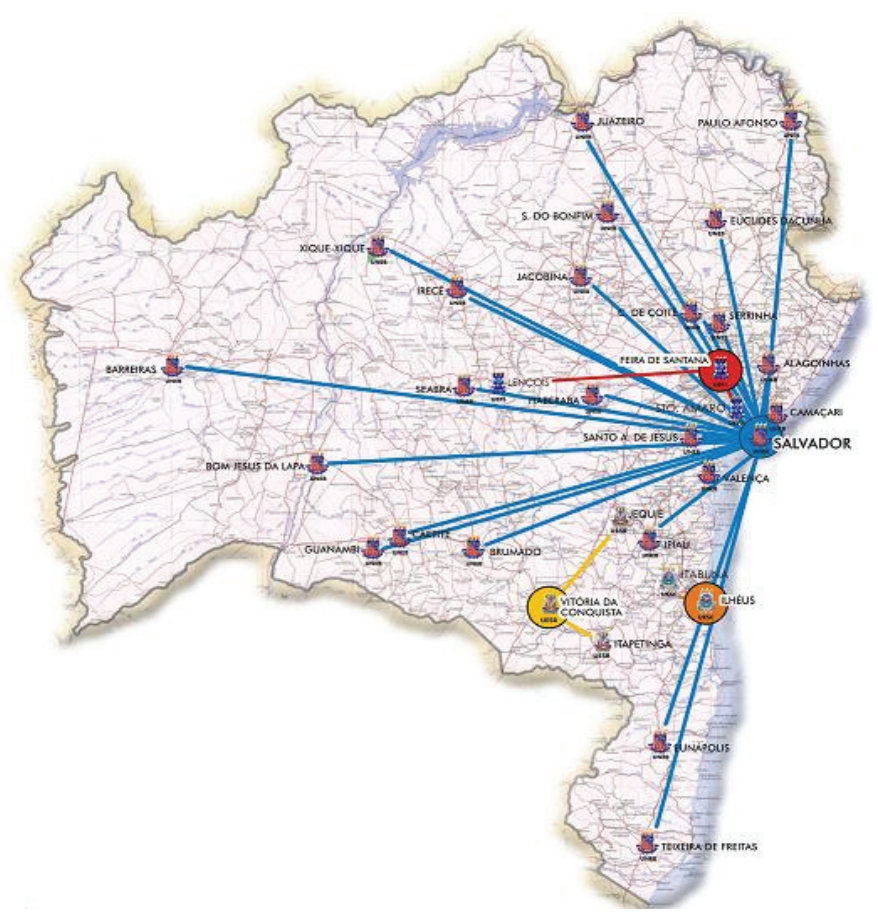

Figura 2 - Mapa de Localização dos campi da Uneb, Uefs, Uesc e Uesb.

Fonte: (BAHIA, 2010, p. 23).

O mapa mostra as cidades-sede que hoje abrigam as universidades, bem como os respectivos campi. As peculiaridades e particularidades que conferiram originalidade ao processo inicial de constituição de cada uma dessas universidades em foco - um sentido único para cada uma delas - contribuíram para a sua caracterização a partir das singularidades que apresentam.

Alguns autores avaliam o papel de Luiz Viana Filho em um quadro que se traçava desde a década de 50 buscando a inserção da Bahia em um projeto desenvolvimentista nacional, conforme descrito anteriormente por Dantas Neto (2003) e caracterizado como modernização conservadora.

De acordo com Dias (2000), a Comissão de Planejamento Econômico, que fora criada por Rômulo Almeida quando secretário da Fazenda do governo de Antônio Balbino (1955-1958), iniciou tal processo de modernização, cujo lema era modernizar a Bahia a partir do ideário do desenvolvimento, liberalismo, progresso, sem grandes mudan- 
ças nas estruturas sociais. A educação tinha um papel coadjuvante no desenvolvimento econômico pretendido (DIAS, 2000).

De acordo com Silva e Pina (2009), o governo Luiz Viana Filho (19671971) parece ter inovado no sentido de inverter o ideário de Antônio Balbino de "[...] enriquecer para educar [...]" para "[...] educar para enriquecer [...]", o que ainda significava o alinhamento do programa desenvolvimentista, só que com investimento em educação. As autoras descrevem o empenho de Luiz Navarro de Brito, primeiro secretário de educação do governador Luiz Viana, no diagnóstico do quadro educacional baiano e no planejamento, Plano Integral de Educação e Cultura (Piec), para atender às áreas mais desassistidas. Conforme as autoras, o Piec teve dificuldades de ser implantado por força das restrições impostas por grupos das elites políticas baianas que marcaram sua oposição a Navarro de Britto, resultando no seu afastamento da Secretaria de Educação antes do final do governo Luiz Viana Filho. Dessa forma, "[...] aquela tentativa de planificação da educação balizada por uma orientação política menos submissa aos vícios das relações de poder instaladas no Estado seria arrefecida" (SILVA; PINA, 2009, p. $67)^{5}$. As autoras citam o secretário Luiz Navarro de Britto e sua reflexão sobre os acontecimentos que marcaram os embates entre ele e algumas elites baianas em relação ao planejamento da educação e seu impacto nas estruturas sociais mais arraigadas.

Mas repensar a educação significa também, necessariamente, revisar as relações de poder. Em uma região subdesenvolvida, isso é ainda mais verdadeiro que alhures, pois as mudanças no setor educativo subvertem em espaço muito curto as raízes sociopolíticas. Como serviço público, a rede educacional nele consiste um dos elementos inerentes ao exercício do patriarcalismo político. Desde o recrutamento do professor até a distribuição do material escolar, da construção da escola até a seleção dos alunos, tudo emanava na Bahia do prestígio e das prerrogativas dos donos dos currais elei-

5 Entretanto, há de se considerar que houve avanços a partir da atuação do professor Edivaldo Machado Boaventura como secretário de educação que sucedeu Luiz Navarro de Brito e deu prosseguimento ao investimento na formação de professores em toda a Bahia, bem como na ampliação no número de matrículas nas séries iniciais e no $2^{\circ}$ grau. De acordo com Boaventura (1978), entre os anos de 1965 e 1975, houve um crescimento considerável nas matrículas para o $1^{\circ}$ grau, da ordem de $7,2 \%$, e para o $2^{\circ}$ grau, de $15,5 \%$. 
torais. Ora, o planejamento em execução desconhecia e repudiava esse 'protecionismo'. Em tais condições, a realização do Piec suscitou resistências, sobretudo indiretas ou disfarçadas. As elites não queriam parecer 'contra' e não podiam também renunciar a seus privilégios (BRITTO, 1991, p. 20 apud SILVA; PINA, 2009, p. 67).

O quadro traçado pelo secretário descreve a resistência das elites tradicionais baianas às mudanças na educação da Bahia, no que tange à melhor estruturação das escolas de primeiro e segundo graus, além do investimento no ensino superior com vistas à democratização e maior qualidade do sistema de ensino público no estado como vetor para o desenvolvimento. Dessa forma, o projeto de potencializar a educação do governo Luiz Viana - lembrando que ele fora indicado pelo governo militar para conduzir o desenvolvimento baiano nos moldes nacionais - encontrou a resistência das elites e grupos oligárquicos, que viam na educação uma ameaça aos seus interesses. Destarte, a máxima de que a educação seria o vetor primordial para o desenvolvimento econômico não se concretizou como uma política efetiva a partir da sua democratização e da configuração de uma intervenção com "[...] espectros mais profundos [...]" que conduzisse à melhoria dos níveis de formação mais condizentes com as mudanças econômicas do período (SILVA; PINA, 2009, p. 68).

Esse panorama de sociedade tradicional trouxe reflexos na estruturação da educação superior na Bahia, dentre os quais se ressaltam: (i) a falta de empenho de algumas de suas lideranças políticas nas mediações necessárias para a ampliação das universidades federais; e (ii) a demora entre o ato de criação de muitas faculdades estaduais e o momento em que realmente entravam em funcionamento (quando entravam). Essas faculdades, posteriormente universidades, foram, como se verá a seguir, resultantes mais da capacidade de pressão da sociedade civil do que da boa vontade dos governos e de algumas elites, conforme atestam muitos entrevistados.

Com base nos depoimentos dos atores que participaram do processo criação da rede de universidades estaduais da Bahia e na leitura de documentos oficiais, matérias de jornais, dentre outros, evidenciou-se a ampliação da oferta e a interiorização da educação superior a partir da década de 80, período da redemocratização, no governo João Durval Carneiro, tendo como secretário o professor Edivaldo Machado 
Boaventura. Assim, o segundo Plano de Educação e Cultura da Bahia (1984-1987) apresenta uma diretriz educacional expansionista.

Desta forma, na década de 80, a criação da Universidade do Estado da Bahia e da Universidade do Sudoeste Baiano, por meio de leis delegadas estaduais, permitiu a agregação de faculdades já existentes, muitas delas fruto de iniciativas de particulares. Na década de 90, é incorporada ao sistema de ensino superior estatal a última universidade, a Universidade Estadual de Santa Cruz, também seguindo o modelo de agregação de faculdades (SANTOS, 2000, p. 41). O Quadro 1 apresenta, de forma mais sistemática, esses acontecimentos.

\begin{tabular}{|c|c|c|c|c|}
\hline $\begin{array}{c}\text { Faculdades predeces- } \\
\text { soras criadas entre as } \\
\text { décadas de } 60 \text { e } 70\end{array}$ & $\begin{array}{l}\text { Período de } \\
\text { transição }\end{array}$ & $\begin{array}{l}\text { Univer- } \\
\text { sidades } \\
\text { Atuais }\end{array}$ & $\begin{array}{l}\text { Ano de Cria- } \\
\text { ção/ Governo }\end{array}$ & $\begin{array}{l}\text { Leis Esta- } \\
\text { duais de } \\
\text { Criação } \\
\end{array}$ \\
\hline $\begin{array}{l}\text { Faculdade Estadual de } \\
\text { Educação de Feira de } \\
\text { Santana }\end{array}$ & $\begin{array}{l}\text { Fufs (Funda- } \\
\text { ção Universi- } \\
\text { tária de Feira } \\
\text { de Santana) }\end{array}$ & Uefs & $\begin{array}{l}1969 \\
\text { Luiz Viana } \\
\text { Filho }\end{array}$ & $\begin{array}{c}\text { Lei } \mathrm{n}^{\circ} \\
2.784 / 70\end{array}$ \\
\hline $\begin{array}{l}\text { Faculdades de Forma- } \\
\text { ção de Professores de } \\
\text { Alagoinhas, Faculdades } \\
\text { de Formação de Pro- } \\
\text { fessores de Jacobina, } \\
\text { Faculdades de Forma- } \\
\text { ção de Professores de } \\
\text { Santo Antônio de Jesus, } \\
\text { Faculdades de Filosofia, } \\
\text { Ciências e Letras de Ca- } \\
\text { etité, Ceteba, Faculdade } \\
\text { de Agronomia do Médio } \\
\text { São Francisco Faculda- } \\
\text { des de Filosofia, Ciências } \\
\text { e Letras de Juazeiro }\end{array}$ & $\begin{array}{l}\text { Ceteba (Cen- } \\
\text { tro Técnico } \\
\text { de Educação } \\
\text { da Bahia), } \\
\text { Seseb (Supe- } \\
\text { rintendência } \\
\text { de Ensino } \\
\text { Superior do } \\
\text { Estado da } \\
\text { Bahia) }\end{array}$ & Uneb & $\begin{array}{l}1983 \\
\text { João Durval. } \\
\text { Carneiro }\end{array}$ & $\begin{array}{c}\text { Lei } \\
\text { Delegada } \\
n^{\circ} \\
66 / 83\end{array}$ \\
\hline $\begin{array}{l}\text { Faculdades de Educação } \\
\text { de Vitória da Conquista; } \\
\text { Faculdade de Forma- } \\
\text { ção de Professores } \\
\text { de Jequié; Escola de } \\
\text { Agronomia de Vitória } \\
\text { da Conquista; Escola de } \\
\text { Enfermagem de Jequié; } \\
\text { Escola de Zootecnia de } \\
\text { Itapetinga }\end{array}$ & $\begin{array}{l}\text { Fundação } \\
\text { Educacional } \\
\text { do Sudoeste }\end{array}$ & Uesb & $\begin{array}{c}1980 \\
\text { Antônio } \\
\text { Carlos Maga- } \\
\text { Ihães } \\
\left(2^{\circ} \text { governo }\right)\end{array}$ & $\begin{array}{c}\text { Delegada } \\
\mathrm{n}^{\circ} 12 \text { de } \\
1980\end{array}$ \\
\hline
\end{tabular}




\begin{tabular}{|l|c|c|c|c|}
\hline $\begin{array}{c}\text { Faculdades predeces- } \\
\text { soras criadas entre as } \\
\text { décadas de 60 e 70 }\end{array}$ & $\begin{array}{c}\text { Período de } \\
\text { transição }\end{array}$ & $\begin{array}{c}\text { Univer- } \\
\text { sidades } \\
\text { Atuais }\end{array}$ & $\begin{array}{c}\text { Ano de Cria- } \\
\text { ção/ Governo }\end{array}$ & $\begin{array}{c}\text { Leis Esta- } \\
\text { duais de } \\
\text { Criação }\end{array}$ \\
\hline $\begin{array}{l}\text { Faculdade de Direito } \\
\text { de Ilhéus; Faculdade } \\
\text { de Filosofia de Itabuna; } \\
\begin{array}{l}\text { Faculdade de Ciências } \\
\text { Econômicas de Itabuna }\end{array}\end{array}$ & Fespi & Uesc & $\begin{array}{c}1991 \\
\text { Antônio } \\
\text { Carlos Maga- } \\
\text { Ihães } \\
\left(3^{\circ} \text { governo) }\right.\end{array}$ & $\begin{array}{c}\text { Lei no } \\
6.344\end{array}$ \\
\hline
\end{tabular}

Quadro 1 - Ensino superior estadual na Bahia - das Faculdades de Formação às Universidades.

Fonte: Pesquisa de campo a partir de dados da SEC/Codes, 2009-2010.

\section{UMA ANÁLISE SOBRE A IMPORTÂNCIA DAS UNIVERSIDADES ESTADUAIS BAIANAS PARA O DESENVOLVIMENTO DO ESTADO}

Algumas inferências foram feitas pelos depoentes desta pesquisa acerca do que, para eles, significariam as mudanças ocorridas nas cidades e regiões onde se estabeleceram universidades até os dias atuais. Sobre esse tema, as respostas dos entrevistados foram agregadas em oito unidades temáticas, expostas na Figura 3.

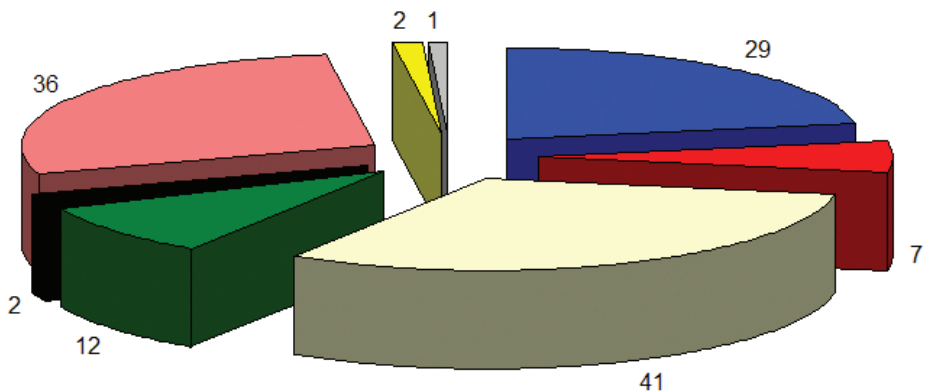

Desenvolvimento/progresso social, econômico e cultural das regiões baianas/ crescimento da população/
mudança na pirâmide social
$\square$ Acesso à ciência e tecnologia/ desenv. da pesquisa/ estreita a relação saber, conhecimento e vida cotidiana
$\square$ Ampliação acesso para o jovem/ Qualificação da juventude/ sociedade mais inteligente/ Melhores
profissionais p/ empresas/ Motivação para estudar e fixação de jovens
$\square$ Formação docente nas escolas públicas/qualidade da educação pública/
Estaduais não são objeto de desejo das elites
$\square$ Mentalidade: olhar mais crítico, político e progressista/ Forma lideranças políticas/ desenv. institucional/
preservação do meio ambiente
$\square$ Nivel de educação ainda precisa melhorar/ precisa mais ênfase no desenvolvimento cientítico e tecnológico
$\square$ Influência não significativa na formação do pesamento social e político/

Figura 3 - Principais mudanças nas regiões e municípios onde foram implantadas universidades.

Fonte: Pesquisa de campo, 2009-2010. 
Dentre as principais mudanças indicadas pelos entrevistados como reflexo do papel da universidade no interior da Bahia, está a categoria que engloba formação, qualificação e fixação dos jovens na região, sociedade mais inteligente, com 41 ocorrências nas entrevistas. Sobre isso, os seguintes trechos são ilustrativos:

Se houver alguém que se disponha a fazer uma pesquisa do impacto na mobilidade social em alguns setores sociais vinculados à rede pública vai descobrir coisas muito interessantes. Eu tenho vários alunos que hoje são profissionais na vida da cidade em várias áreas e tal e, sobretudo, alunos de origem muito humilde e que são mestres e doutores; têm alunos que já fizeram curso no exterior, tem aluno na USP, têm alunos que são professores da USP, que se formaram em Vitoria da Conquista (Entrevista, . $^{\circ} 27$ ).

Corroborando esse entendimento, Buarque (1994) realiza um estudo sobre a importância da presença de universidades fora das capitais do estado, em cidades menores, para a fixação dos jovens e também de profissionais. Para o autor, sem elas, os jovens acabariam migrando para os grandes centros urbanos. Também para os jovens professores recém-formados, a universidade surge como possibilidades de inserção social.

Eu acho que, se não existisse a Uesc, aquela região não sobreviveria. Foi fundamental para a região. Hoje, [a Uesc] tem mais de 3000, 4000 alunos. Onde estariam esses alunos sem a universidade? Seriam vendedores em lojas e não teriam oportunidade de estudar em Salvador. Tem grandes professores lá, esses laboratórios estão prestando serviços de modo geral na região, impactos sobre a comunidade de baixa renda. Há uma interação muito grande. São Longuinho, que é um vilarejo em frente, vive em função da universidade. Lá eu criei cursos de $1^{\circ}$ e $2^{\circ}$ grau para a turma do vilarejo. Eu não sei o que seria da região se nós não tivéssemos dado esse passo (ENTREVISTA, $n^{\circ} 8$ ).

Esse depoimento é confirmado por pesquisas que retratam o número de matriculados nas Universidades Estaduais Baianas (UEBAs). De acordo como o Inep, em 2005, na Bahia, existiam 82.026 
alunos frequentando o ensino superior; desses, quase a metade - 40.843 - estava matriculada nas universidades estaduais, distribuídas em trinta e um municípios baianos. Ainda de acordo com o Inep, 20.293 alunos estavam matriculados na Uneb, a principal ofertante de vagas entre as estaduais. Já em 2008, a Uneb se destaca entre as 30 universidades brasileiras em número de matrículas, com 22.486 alunos. A despeito do papel das universidades estaduais na oferta de vagas de nível superior, o relatório conclui que o acesso ao ensino superior para os baianos ainda é extremamente baixo, se comparado com os índices nacionais. Em 2005, na população de 18 a 22 anos, 4,9\% frequentam instituições de ensino superior na Bahia, quando a média do Distrito Federal, cidade com maior número de matrículas, é de 22,9\% (BRASIL, 2001).

Já em 2009, no total das universidades estaduais, de acordo com o relatório da Codes, "[...] matricularam-se nos 322 cursos de graduação (219 em oferta contínua e 103 em Programas Especiais) 49.080 estudantes (39.595 em oferta contínua e 9.485 em Programas Especiais). Do total de matrículas, 30.911 se efetivaram nos 207 cursos de Licenciatura, e 18.169 nos 115 cursos de Bacharelado" (BAHIA, 2010, p. 4).

Um segundo fator muito apontado foi a mudança nas mentalidades e formação das lideranças políticas, com 36 ocorrências, seguido de desenvolvimento social, cultural e econômico da região, com 29 ocorrências. Esses elementos ressaltam o papel da educação para a formação do sujeito e de sua capacidade de emitir julgamentos, pois favorece uma compreensão dos fenômenos menos simplificada (ou alienada) e mais crítica e política.

A cultura é um aspecto tão destacado no decorrer das entrevistas, quanto ao desenvolvimento econômico dos municípios sob o raio de ação das universidades estaduais. Nesse sentido, tão importantes quanto as entrevistas, no sentido de apreender essas nuanças, foram as vivências da pesquisa de campo, que fornecem um rico material para análise, que diz respeito a: conversas mais informais com alunos, professores, técnicos, pessoas da comunidade; visitas aos museus e espaços diversos das universidades, voltados para a promoção do conhecimento; participação nos eventos promovidos - como exposições fotográficas, teatro a céu aberto, festivais 
etc. Conforme o relato que inicia este capítulo, os saberes das universidades invadem as comunidades. O sentido de invasão aqui é emblemático: influenciar ou mudar as estruturas sociais cristalizadas, despertar o interesse, a curiosidade, romper com o comodismo, o imobilismo (necessário para que um sistema excludente se mantenha), apresentar o novo, o saber que liga a realidade local a conhecimentos universais.

Ainda que, por si só, a universidade não assegure a promoção da justiça social, ela pode ser capaz de tornar as sociedades menos desiguais e mais integradas. A aquisição de conhecimentos hoje, como dantes, é a condição indispensável para que as pessoas possam ter inserção social, seja no seu aspecto mais utilitário e visível, relacionado às habilitações, seja a partir de uma visão mais ampla dos valores, com relação ao conhecimento como base da cidadania a ser exercida em sociedades cada dia mais plurais, complexas, onde são construídos espaços de equilíbrios instáveis que envolvem conflitos e necessidade de negociação por parte dos atores.

Para Teixeira (1953), a base, o fundamento e a condição da existência da democracia é a educação. E quais são as dificuldades de instituição da democracia? O burocratismo antidemocrático do estado, as estruturas arcaicas patrimonialistas e oligárquicas, a estrutura extremamente desigual da sociedade, o analfabetismo, a educação superior como privilégio de poucos. Uma estrutura que impede o reconhecimento de direitos, sua reivindicação e garantia, ou o surgimento de um ser autorreconhecido, conforme Honneth (2003).

A formação dos docentes para as escolas públicas, que teria sido de início o mote do governo estadual, não aparece aqui como um elemento tão relevante, perfazendo 12 ocorrências no total das entrevistas. O que significa que a universidade supera as expectativas iniciais de sua implantação, conforme foi discutido.

Dois outros posicionamentos consideram que as universidades estaduais não têm influência significativa na formação do pensamento social e político, com 1 indicação e 2 ocorrências sobre o fato de elas não serem objeto de desejo de elites. Essas informações foram justificadas a partir da comparação das universidades estaduais com as universidades federais, que teriam maior prestígio social. 
No que tange ao desenvolvimento da pesquisa e acesso à ciência e tecnologia, há 7 ocorrências. Para essa questão, também há a indicação por parte dos entrevistados de que as universidades têm investido cada dia mais no incentivo à qualificação docente e na pesquisa de maneira geral, mesmo que precisem ainda avançar muito nessa questão, pois apontam também a necessidade de as universidades melhorarem o nível de educação no sentido do desenvolvimento de ciência e tecnologia (2 ocorrências). Como se sabe, a origem da maioria das faculdades que se transformaram nas atuais universidades foi a formação de professores; somente com o passar do tempo, com as demandas sociais e o papel dos professores e estudantes, elas passaram a investir mais em pesquisa e desenvolvimento da ciência, por meio da oferta de novos cursos, da pós-graduação, da qualificação dos professores. Portanto, pode-se dizer que estão em processo de desenvolvimento e de afirmação como instituições de pesquisa.

De acordo com relatório da Coordenação para o Desenvolvimento do Ensino Superior - Codes, órgão ligado à Secretaria de Educação -, hoje, as universidades estaduais contam com 2.773 professores efetivos entre mestres e doutores, o que contribui para o adensamento das atividades voltadas para o desenvolvimento da pesquisa. A qualificação dos docentes (titulação acadêmica) ao longo dos anos pode ser considerada como um aspecto importante na análise da reformatação do papel dessas universidades.

O Quadro 2 apresenta a avaliação das universidades estaduais de acordo com o Índice Geral de Cursos (IGC). Trata-se de um indicador utilizado para medir a qualidade das instituições de ensino superior, considerando tanto os cursos de graduação como os de pós-graduação (mestrado e doutorado). No caso da graduação, uma das medidas utilizadas é o desempenho no Enade; no caso da pós-graduação, é a nota Capes. O resultado final está em valores contínuos (que vão de o a 500) e em faixas (de 1 a 5). 


\begin{tabular}{|c|c|c|c|c|}
\hline \multirow[b]{2}{*}{ Universidades } & \multirow{2}{*}{$\begin{array}{l}\text { Número de } \\
\text { cursos que fi- } \\
\text { zeram Enade } \\
\text { nos últimos } 3 \\
\text { anos }\end{array}$} & \multirow{2}{*}{$\begin{array}{l}\text { Número de } \\
\text { cursos com } \\
\text { CPC* nos } \\
\text { últimos } 3 \\
\text { anos }\end{array}$} & \multicolumn{2}{|c|}{ IGC } \\
\hline & & & $\begin{array}{l}\text { Contí- } \\
\text { nuo }\end{array}$ & Faixas \\
\hline $\begin{array}{l}\text { Universidade do Estado da } \\
\text { Bahia }\end{array}$ & 116 & 53 & 252 & 3 \\
\hline $\begin{array}{l}\text { Universidade Estadual de } \\
\text { Feira de Santana }\end{array}$ & 19 & 17 & 220 & 3 \\
\hline $\begin{array}{l}\text { Universidade Estadual de } \\
\text { Santa Cruz }\end{array}$ & 22 & 21 & 298 & 4 \\
\hline $\begin{array}{l}\text { Universidade Estadual do } \\
\text { Sudoeste Baiano }\end{array}$ & 33 & 23 & 255 & 3 \\
\hline $\begin{array}{l}\text { Universidade Federal da } \\
\text { Bahia }\end{array}$ & 46 & 38 & 325 & 4 \\
\hline $\begin{array}{l}\text { Universidade Fed. do Recôn- } \\
\text { cavo Baiano }\end{array}$ & 12 & 1 & 197 & 3 \\
\hline $\begin{array}{l}\text { Universidade Estadual do } \\
\text { Maranhão }\end{array}$ & 151 & 42 & 210 & 3 \\
\hline $\begin{array}{l}\text { Universidade Estadual do } \\
\text { Ceará }\end{array}$ & 49 & 44 & 245 & 3 \\
\hline $\begin{array}{l}\text { Universidade Estadual da } \\
\text { Paraíba }\end{array}$ & 31 & 25 & 245 & 3 \\
\hline $\begin{array}{l}\text { Universidade do Estado do } \\
\text { R.G. do Norte }\end{array}$ & 69 & 36 & 246 & 3 \\
\hline $\begin{array}{l}\text { Universidade Estadual de } \\
\text { Alagoas }\end{array}$ & 19 & 14 & 185 & 2 \\
\hline $\begin{array}{l}\text { Universidade de } \\
\text { Pernambuco }\end{array}$ & 35 & 32 & 215 & 3 \\
\hline
\end{tabular}

Quadro 2 - Índice Geral de Cursos da Instituição - IGC 2008 (triênio 2006, 2007, 2008), para universidades públicas da Bahia e estaduais do Nordeste.

Fonte: Brasil (2001). * Conceito preliminar de cursos (CPC).

Pode-se observar que as universidades baianas estão na faixa da maioria das universidades estaduais do Nordeste e acima das estaduais de Alagoas e Piauí, sendo que a Uesc se destacou como um conceito quatro, tal como a UFBA, um desempenho registrado em apenas $6 \%$ das instituições de ensino superior avaliadas. 
Assim como se procurou demonstrar no início, buscou-se fazer uma avaliação do entendimento que os entrevistados têm sobre o papel das universidades estaduais hoje. Em uma questão específica e aberta, perguntou-se exatamente isso. As diversas opiniões foram condensadas em seis categorias, conforme é apresentado na Figura 4.

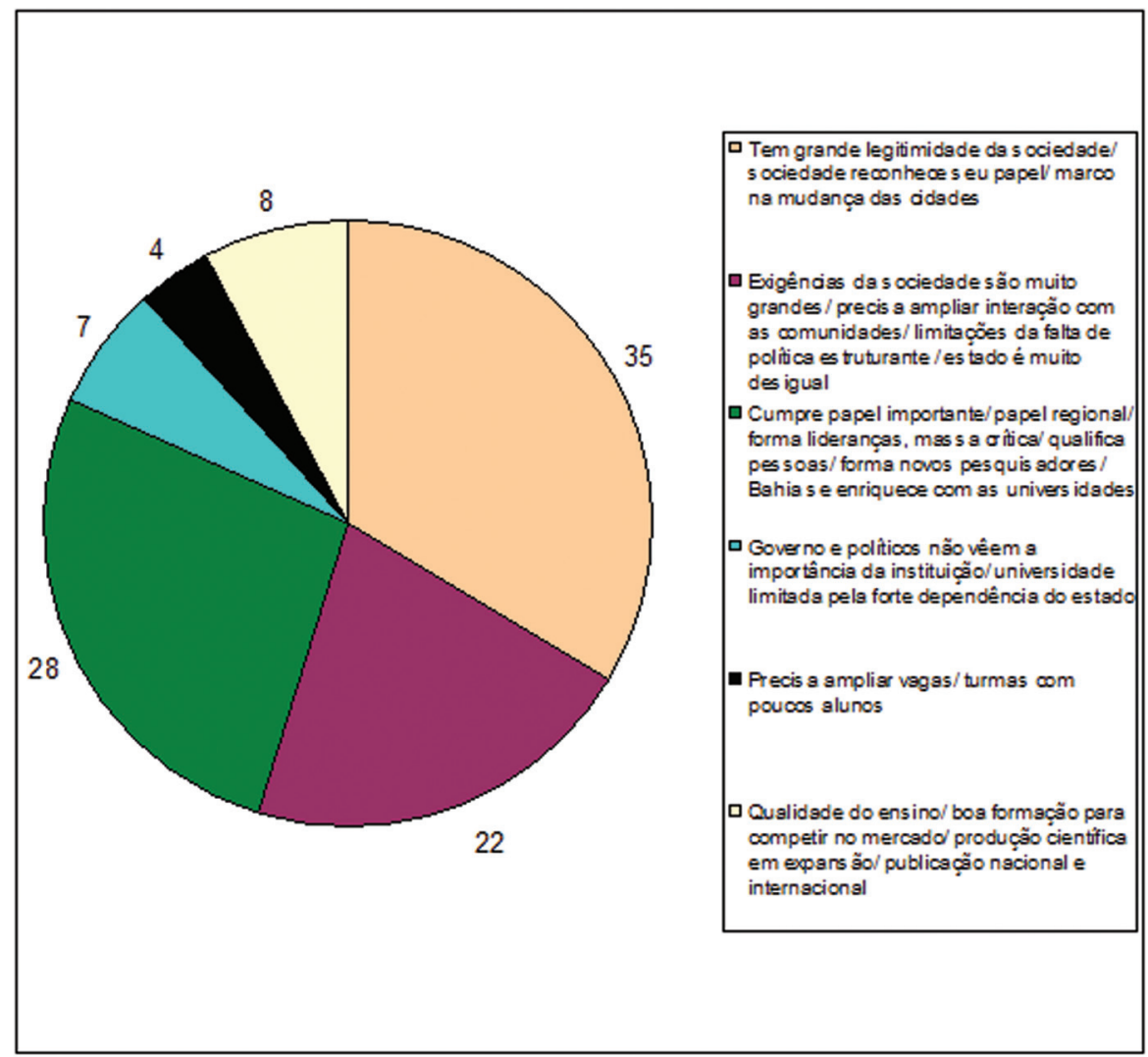

Figura 4 - As universidades estaduais têm correspondido às expectativas da sociedade?

Fonte: Pesquisa de campo, 2009-2010.

O elemento que agregou o maior número de indicações refere-se à legitimidade da rede de universidades estaduais, pelo fato de elas representarem um marco na mudança das cidades, com 35 indicações. A legitimidade das universidades apontada pelos entrevistados advém do cumprimento do seu papel ao longo dos anos nas comunidades e regiões onde se instalaram. 
O segundo fator mais mencionado reforça essa ideia com o entendimento de que elas cumprem seu papel, com 28 indicações que focalizam a sua importância para as regiões e para o país em geral, por formar indivíduos, mudar mentalidades, criar lideranças políticas. Com relação a esse último aspecto, os informantes entendem que o ambiente da universidade pode ser capaz de contribuir para a formação de indivíduos mais críticos.

Com 22 indicações, foram condensadas as referências dos entrevistados aos limites do papel das universidades estaduais, que são problemas debatidos por estudiosos do tema, como Souza Santos (1999), que se refere justamente à diversidade de papéis, anteriormente referida, que a instituição é cobrada a assumir tanto pela sociedade, quanto pelo estado. Além de apontar caminhos para o desenvolvimento da sociedade com o conhecimento científico, a universidade tem sido cobrada no que tange à articulação entre esse saber e a realidade.

Com 8 indicações, os entrevistados ressaltam a qualidade do ensino oferecido pelas universidades. Sobre esse item, e conforme exposto, as universidades estaduais têm sido relativamente bem avaliadas por instâncias oficiais. Carecem de mais investimentos em pesquisa, de revisão de cursos oferecidos e sem demanda, de maior aporte de investimentos públicos, de revisão do modelo de gestão com vistas a reafirmar a sua vocação regional, aspectos ressaltados pelos entrevistados ao longo dos depoimentos.

Com 7 indicações, retoma-se a crítica ao papel do governo, no sentido de não investir mais, e 4 indicações esboçam a necessidade de as universidades ampliarem o número de vagas, fazendo-se referência ao percentual ainda não desejável de formados em nível superior na Bahia.

São recorrentes, no grupo dos entrevistados, os relatos que apontam a falta de prioridade dispensada pelo governo do estado às universidades, aliada a uma cobrança cada dia maior de retornos quantificáveis. Sobre isso, é fato que a política do governo para a educação tem-se orientado por diagnósticos internacionais, fato recorrente na história das universidades brasileiras. O Banco Mundial (1995) tem orientado, em seus relatórios, que o investimento público deva se concentrar na educação básica, indicando que os 
demais níveis - secundário e superior - devam adotar a cobrança de taxas e, no caso da universidade, a adoção de empréstimos para alunos que não possam pagar. Destarte, a concepção de universidade tem sido voltada para princípios produtivistas ou mercadológicos, com influência negativa para as instituições. Assim, a falta de recursos e de autonomia, tão mencionada nas entrevistas, diz respeito a um quadro mais amplo de reforma do estado. Autores como Draibe (1993) consideram os efeitos negativos das políticas neoliberais ${ }^{6}$ nas universidades públicas, como a redução orçamentária, o estímulo à busca por financiamento privado para o desempenho das ações das universidades, buscando condicionar a universidade pública à lógica de mercado e distanciando-a do seu ideal clássico de pesquisa, ciência, cultura e formação. Para Souza Santos (1999), o ideal de universidade começa a se descaracterizar nos anos 60, quando se atribui a ela inúmeros papéis - prestação de serviços ou extensão, qualificação da mão de obra, preparação para quadros políticos e de liderança empresarial, dentre outros -, muitos deles contraditórios, configurando as três crises da universidade, conforme já discutido.

Em um resumo sobre o papel das universidades estaduais, elaborou-se a Figura 5 a partir do núcleo das representações. É importante destacar que, quanto mais próxima de um (1), maior a frequência (dada pelo número de vezes em que a palavra foi citada) e a intensidade dos valores (dada pela posição da palavra na ordem da enunciação), mais cristalizados eles são.

Nessa síntese, os entrevistados têm a possibilidade de falar de maneira sintética, abreviada e objetiva sobre o tema ${ }^{7}$.

6 Perry Anderson (1995) considera o neoliberalismo como "[...] uma reação teórica e política ao estado de bem-estar [...]”, que prega a intervenção mínima do estado na economia e na sociedade. Para Théret (2007), o neoliberalismo define um "[...] sistema de receitas práticas para a gestão pública [...]”, em que o mote é racional-instrumental, e as noções norteadoras se referem a produtividade, eficiência, rapidez. Isso, por sua vez, aplicado às universidades, transforma o seu papel de centros de saber desinteressado para o de produção e aplicabilidade prática. 7 Nessa questão, um conjunto de categorias foi elaborado a partir do enunciado das falas dos entrevistados e dizem respeito à sua percepção sobre a configuração atual das universidades estaduais na Bahia. Na questão, foi solicitado que os entrevistados indicassem 3 ou 4 palavras ou sentenças que resumissem sua percepção sobre o tema proposto. Em seguida, as informações foram categorizadas e apresentadas a partir do gráfico do núcleo central das representações. Em linhas gerais, o núcleo das representações permite compreender a combi- 


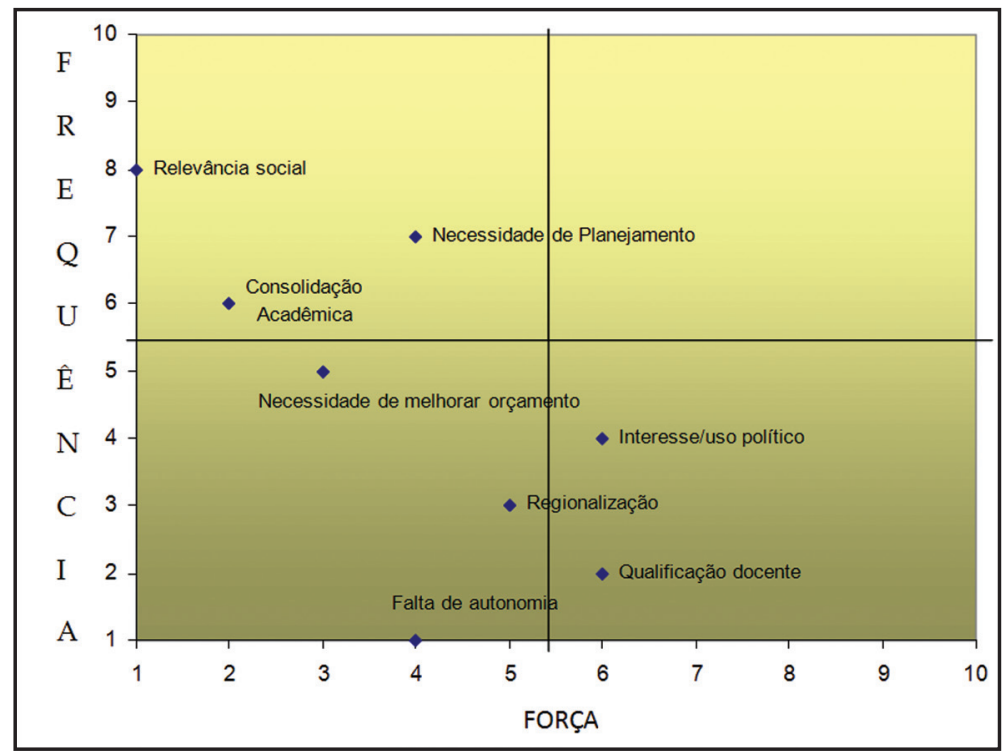

Figura 5 - As universidades estaduais têm correspondido às expectativas da sociedade?

Fonte: Pesquisa de campo, 2009-2010.

Como se pode perceber, aliam-se, nesse gráfico, elementos que ressaltaram a importância do papel dessas instituições e aspectos mais críticos que permearam o conjunto das entrevistas.

Relevância social aparece em primeiro lugar no que tange à força ou o grau de relevância que teve na fala dos entrevistados. Em segundo lugar está consolidação acadêmica. Esses dois aspectos foram os mais marcantes apontados no conjunto das entrevistas.

Com a criação da universidade, a região cacaueira se protegeu para subsistência de sua economia e fincou os pilares de sustentação do seu futuro. Com a crise da vassoura de bruxa, a universidade passou a ser um grande antídoto para as crises e, ao mesmo tempo, você estabeleceu a sustentação para o enfrentamento do futuro. A história da civilização da região

nação entre a frequência da evocação do enunciado (citar livremente valores e sentimentos referentes sobre um determinado tema) e a posição média da evocação (ordem de importância dada a cada palavra ou sentença), o que tem a ver com o grau de relevância atribuído a cada elemento citado no conjunto das respostas (SÁ, 1996). 
do cacau da Bahia divide-se em duas etapas: antes e depois da universidade. Numa região de tradição coronelista, a universidade significa o espaço para vicejar os espíritos livres e a libertação das amarras criadas pelos tabus e preconceitos (UNIVERSIDADE ESTADUAL DE SANTA CRUZ, 1999).

Também a regionalização é fator marcante, relembrando que o mote de nascimento dessas instituições foi justamente constituído pelas demandas e carências regionais. A LDB de 1996, em seu artigo 43, especifica as diretrizes da instituição universitária para além do papel formativo, referindo-se à necessária relação entre a ela e a sociedade: "VI - estimular o conhecimento dos problemas do mundo presente, em particular os nacionais e regionais, prestar serviços especializados à comunidade e estabelecer com esta uma relação de reciprocidade; e VII - promover a extensão, aberta à participação da população, visando à difusão das conquistas e benefícios resultantes da criação cultural e da pesquisa científica e tecnológica geradas na instituição" (BRASIL, 1996). Hoje, em sua consolidação, as universidades estaduais reafirmam essa perspectiva de integração com as questões regionais como a sua maior potencialidade, pois é aí que se pode mais fortemente influenciar estruturas sociais, constituir capital social, mudar aos poucos uma cultura política. Isso porque à universidade cabe não só formar profissionais, mas também gerar conhecimento, arte, cultura, identidade, valores.

Retomam-se os elementos de crítica mais marcantes, antes indicados, que são a necessidade de melhorar orçamento e a falta de autonomia, que tiveram alta frequência e intensidade nas respostas (pois foram citados entre os primeiros).

Ao tempo em que as universidades baianas redefinem e ampliam o seu papel, aproximando-se das comunidades, têm de conviver com uma situação de orçamentos restritos. Tais críticas significam que a universidade tem problematizado o atual contexto de desmonte do estado, pela defesa de uma bandeira de luta inscrita na sua história, a da "universidade pública, gratuita e de qualidade". São instituições que estão constantemente discutindo o seu papel no sentido da orientação pela qualidade de suas ações, seja na pesquisa, no ensino ou na extensão. A condição da universidade 
pública brasileira é discutida por estudiosos do tema como Ristoff (1999), Dagnino (1985) e outros, que acentuam que o Brasil de influência neoliberal tem adotado cortes de gastos públicos como se não visse a educação como um investimento, mas como um gasto. No caso das universidades estaduais, conforme foi destacado, há grande ênfase na insuficiência dos recursos públicos, aliada a uma espécie de competição entre os níveis diferenciados de ensino. Esse fato reflete um não entendimento da educação de uma forma sistêmica, em que todos os níveis de ensino se influenciam e se retroalimentam. Além disso, consolida-se um discurso de que o estado baiano não tem obrigação para com a educação superior, porque isso seria papel do governo federal, ofuscando os méritos das universidades estaduais, como se tudo o que é realizado em termos de ensino, pesquisa, extensão e produção de conhecimentos adquirisse uma espécie de invisibilidade.

A política nacional e estadual de financiamento da educação tem produzido efeitos perversos nas universidades públicas, na medida em que restringe fontes de recursos, induzindo as instituições a buscarem outras fontes como meio para a sua sobrevivência. Isso tem implicações na própria identidade das instituições públicas de ensino superior (JEZINE; BATISTA, 2008). Ademais, impõe limites à expansão das ações das universidades, tanto quantitativa como qualitativamente (maior oferta de vagas, investimento na pesquisa, qualidade de ensino, infraestrutura adequada).

Tem sido prática comum as universidades recorrerem a suplementações orçamentárias - e, com isso, os reitores veem seu papel muitas vezes associado às negociações com o governo do estado acerca de revisões do orçamento. Do ponto de vista docente, as greves ainda são a estratégia utilizada para pressionar o governo do estado por melhores condições de trabalho, reposições salariais, melhoria da infraestrutura e maior verba destinada às universidades.

Outros elementos que surgiram ao longo das entrevistas reaparecem nessa questão-resumo, como a qualificação do corpo docente, cada dia mais importante para as universidades ampliarem um papel para além do ensino.

Interesse e uso político também reaparecem nessa questão-re- 
sumo, mas com menor intensidade do que os outros elementos que configuram as universidades estaduais. Reafirma-se, então, o entendimento das ambivalências que permearam o processo e os aspectos aqui considerados que melhor descrevem a história das universidades estaduais baianas: as dinâmicas regionais pautadas em identidades e solidariedades geográficas, advindas do entendimento da situação desigual do interior do estado em relação à capital, no tocante ao acesso ao conhecimento e à cultura.

\section{A TíTULO dE CONCLUSÃO}

Neste artigo, buscou-se recuperar o processo de criação das universidades estaduais baianas e a importância das mesmas para o processo de desenvolvimento cultural, econômico e social do estado.

No caso da Bahia, os parâmetros de análise adotados, de caráter sociológico, permitiram compreender mais e melhor as relações tecidas e as mobilizações empreendidas em determinadas regiões, movidas por solidariedades regionais. Tais eventos tornaram explícita, para o poder público e para a sociedade em geral, a situação desigual do interior da Bahia em termos educacionais, notadamente com relação ao ensino superior, nas décadas de 60 e 70. Para Honneth (2003), são as situações de privação que despertam nos indivíduos a percepção da desigualdade e das baixas condições estruturais para a constituição da autoestima, movendo-os para a ação social a partir de uma motivação convergente pautada em experiências compartilhadas.

Com vistas a buscar reconstruir esse processo de criação das universidades, priorizou-se o depoimento dos indivíduos que tiveram uma relação estreita com as diversas instâncias institucionais. Por isso, este estudo de caso, de caráter eminentemente qualitativo, deu ênfase à abordagem descritiva dos dados colhidos a partir das fontes primárias (entrevistas) e secundárias (documentos diversos e matérias de jornais). Recorreu-se à memória de informantes-chave sobre os acontecimentos relativos ao processo de criação das universidades, bem como se buscou correlacionar tais depoimentos com documentos diversos. A história pôde ser recriada pela memória e pelos documentos. Como pesquisa qualitativa, não foi 
pretensão a generalização de resultados, mas a obtenção de informações e registros sobre concepções, entendimentos, tendências e o papel social das universidades em conformidade com o que explicitam os discursos dos informantes.

Um aspecto acentuado nesse processo foi o papel das cidades mais proeminentes, pela sua capacidade de polarização, mobilização e também de pressão junto aos governos. Foi assim que as primeiras faculdades surgiram em contextos sociais dinâmicos, de pujança tanto econômica quanto social. Da parte do Estado da Bahia, houve um planejamento que situava algumas cidades do interior como locais que poderiam se tornar centros difusores de educação. Por esse motivo, neste trabalho, deu-se relevância especial ao lugar e à região como lócus onde a vida se realiza - a cidade é polis, no sentido político e administrativo, e civitas, no sentido da complexidade dos grupos e instituições diversas que abriga -, ressaltando as particularidades de algumas cidades importantes nesse processo, notadamente Feira de Santana, Itabuna e Ilhéus, Vitória da Conquista, dentre outras. Para Santos (1988), a cidade é o lugar primordial da socialização, pois nela está presente o movimento das trocas constantes e, por isso, tem papel fundamental na formação das identidades e solidariedades que são ativadas também por carências diversas. Pode-se dizer que as universidades estaduais de hoje surgiram com uma raiz eminentemente regional, e esse vínculo definiu a particularidade de cada uma delas.

Um segundo elemento derivado da questão das cidades como fontes de sociabilidades refere-se à criação da rede de universidades públicas estaduais como fruto do processo de conscientização de uma posição desigual em relação ao ensino superior (autorreconhecimento). Nesse sentido, um trocadilho de época costumava ser usado - conforme é mencionado nas entrevistas - como crítica à concentração do ensino superior na capital: "Universidade Federal rima com litoral e Universidades Estaduais da Bahia rimam com periferia". Pôde-se perceber que a formação dessas identidades pessoais e coletivas tinha uma motivação de ordem moral, voltada para o respeito aos direitos sociais, no caso o provimento da formação educacional em alto nível. Um tema que ficou manifesto nas entrevistas foi a formação de redes de relações cooperativas e 
solidárias, cujo resultado foi a formatação das primeiras faculdades (privadas, públicas, mistas). Observou-se que, no começo, a despeito da falta de infraestrutura, de verbas e carências de todo o tipo, elas funcionaram a partir do engajamento das pessoas, professores, alunos, grupos da sociedade que apoiaram como puderam - doação de terrenos e prédios para funcionar a faculdade, por exemplo, é fator típico do processo. A noção de solidariedade como aqui entendida refere-se exatamente a essa capacidade da sociedade de associação com vistas a objetivos comuns. Tais considerações puderam ser mais bem avaliadas a partir dos depoimentos, que revelaram toda a complexidade das tramas traçadas em torno da promoção do ensino superior, com ênfase em valores éticos fundamentais, como a responsabilidade, a perseverança como objetividade, a solidariedade como compromisso social. Como afirma Geertz (1978, p. 47), em um texto clássico da antropologia, a natureza humana sempre dependerá do tempo, do lugar e das circunstâncias, e, da mesma forma, o que o homem é dependerá de onde ele está e em que ele acredita. Assim, não há indivíduos que não tenham sido influenciados pelos valores, normas e costumes de lugares e experiências particulares.

Reafirma-se, com este estudo, a importância da universidade pública e a necessidade imperiosa de o conhecimento e o saber pertencerem à humanidade e serem usados em seu beneficio. Quando questionados sobre o que era, para eles, a universidade, os informantes emitiram respostas precisas, que traduziam um sentimento mais ou menos generalizado sobre essa instituição milenar: é produtora de conhecimento, é agente de transformação social, é difusora de ética e tem compromisso político. O compromisso das universidades é voltado para a solução dos novos problemas e também para reafirmar a sua identidade com a região em que está inserida. Nos dias atuais, em que se multiplicam fenômenos desagregadores que impactam sobre os indivíduos - desemprego, má distribuição de renda, dentre outros -, as universidades não podem figurar como uma instituição superior, elitizada e acima da sociedade, porque é a partir delas que se podem elaborar propostas mais integrais de mudança social, pela sua capacidade propositora, pela identificação das causas e possíveis alternativas aos problemas. Essa tarefa é imensa, mas ainda tem a ver com o seu passado 
histórico, quando as universidades fomentaram as ideias de política, autonomia, liberdade, ética e ciência em benefício do homem. Conforme Bernheim e Chauí (2008), o ideal de universidade defendido por Medina Echavia (1967 apud BERHEIM; CHAUÍ, 2008, p. 18) é o da universidade "[...] participante [...]", que significa um meio termo entre a universidade militante (completamente invadida pelas pressões sociais) e a universidade enclausurada (alheia à sociedade), e diz respeito a "[...] uma universidade que participa em todos os aspectos da vida da sociedade, sem perder seu caráter de academia e que só afirma o que é apropriado afirmar na condição de academia" (BERHEIM; CHAUÍ, 2008, p. 17-18).

Essas contribuições destacam a importância da universidade e reafirmam sua função de missão educacional para o desenvolvimento intelectual, científico, cultural e social (TEIXEIRA, 1953, p. 14).

Com uma visão ampla de universidade, que não a reduz a uma mera reprodutora de conhecimento, Anísio Teixeira relaciona a mesma com liberdade e democracia, no sentido de que, em seus limites, é permitido o livre desenvolvimento do homem.

\section{REFERÊNCIAS}

ANDERSON, Perry. Balanço do neoliberalismo. In: SADER, Emir e GENTILI, Pablo (Orgs.). Pós-neoliberalismo. Rio de Janeiro: Paz e Terra, 1995.

BAHIA (Estado). Secretaria de Educação e Cultura (SEC). Coordenação de ensino superior (CODES). Relatório de atividades. 2010, Salvador, 2010.

BANCO MUNDIAL. Educação superior na América Latina e no Caribe - Documento de estratégia. Washington, D.C, julho de 1995. BERNHEIM, Carlos Tünnermann; CHAUÍ, Marilena de. Desafios da universidade na sociedade do conhecimento: cinco anos depois da conferência mundial sobre educação superior / e. Brasília: UNESCO, 2008.

BOAVENTURA, Edivaldo Machado. Espírito de Julgamento. Salvador: Universitária, 1978.107p. 
BRASIL. MEC/INEP/SEEC. INSTITUTO NACIONAL DE ESTUDOS E PESQUISAS EDUCACIONAIS (INEP). INEP, 2001. Disponível em: <http://www.inep.gov.br/download/saeb/2001/Miolo_Novas_Perspectivas2001.pdf>. Acesso em: 04 set. 2008.

BRASIL. Lei n 9.394, de 20 de dezembro de 1996. Estabelece as diretrizes e bases da Educação Nacional. Brasília, 20 dez. 1996. Disponível em: <http://< http://portal.mec.gov.br/seed/arquivos/pdf/ tvescola/leis/lein9394.pdf>.

BUARQUE, Cristovão. A aventura da universidade. São Paulo: UNESP; Rio de Janeiro: Paz e Terra, 1994.

CARNEIRO, Henrique S. História da ciência, da técnica e do trabalho no Brasil. Revista Nuevo Mundo, Mundos Nuevos, Bibliografias, 2002. Disponível em: <http:// nuevomundo.revues.org/index573. html>. Acesso em: 17 jul. 2010.

CUNHA, Luiz Antônio. A universidade reformada: o golpe de 1964 e a modernização do ensino superior. Rio de Janeiro: Francisco Alves, 1988.

. O desenvolvimento meandroso da educação brasileira entre o estado e o mercado. Revista Educação \& Sociedade, v. 28, n. 100, out. 2007.

DAGNINO, R. P. Universidade e Política de C\&T. In: BORI, C. et al. (Org.) Universidade Brasileira: organização e problemas. São Paulo: SBPC, 1985.

DANTAS NETO, Paulo Fábio. "Surf" nas ondas do tempo: do carlismo histórico ao carlismo pós-carlista. Caderno CRH, Salvador, n. 39, p. 213-255, jul./dez. 2003.

- Quebra da casca do ovo: a elite baiana e a obra do golpe de 1964. 2004.Disponível em: <www.fundaj.gov.br/licitacao/observa_ bahia_01.pdf>. Acesso em: 23 out. 2010.

DI LAURO, Aluztane et al. Territórios de identidade no Brasil: uma análise teórica e metodológica no estado da Bahia. Disponível em: <http:/www.gal2009.easyplanners.info/.../2063_Evangelista_Antonia_dos_Reis_Salustiano.pdf>. Acesso em: 3 mar. 2010.

DIAS, André Luis Mattedi. A universidade e a modernização conservadora na Bahia: Edgard Santos e os institutos científicos. Dispo- 
nível em <http:/www.mast.br/arquivos_sbhc/7.pdf>. 2000. Acesso em 23 de agosto de 2010.

DRAIBE, Sônia M. As políticas sociais e o neoliberalismo. Revista da USP, n. 17, mar./maio, 1993.

FÁVERO, Maria de Lourdes de Albuquerque. Autonomia universitária: necessidade e desafios. Cadernos CEDES, n. 22, p. 7-16, 1988.

GEERTZ, Clifford. O impacto do conceito de cultura sobre o conceito de homem. A interpretação das culturas. Rio de Janeiro: Zahar, 1978.

HONNETH, Axel. Luta por reconhecimento: a gramática moral dos conflitos morais. São Paulo: 34, 2003.

IANNI, Otávio. A Idéia de Brasil moderno. 2. ed. São Paulo: Brasiliense, 1996.

JEZINE, Edineide; BATISTA, Maria do Socorro Xavier. Globalização e políticas de ensino superior: as lutas sociais e a lógica mercantilista. In: REDE IBERO AMERICANA DE INVESTIGAÇÃO EM POLÍTICAS DE EDUCAÇÃO. 20 dez. 2008. Anais... Disponível em: <http://www. cyted.riaip.net/índex>. Acesso em: 22 set. 2010.

LIMA, Iracema Oliveira. Desenvolvimento regional e a organização da educação superior estadual baiana. Ciência \& Desenvolvimento: Revista eletrônica da Fainor (c\&d), p.55-60, 2008. Disponível em: <http://srv02.fainor.com.br/revista/index.php/memorias/article/ viewfile/17/14>. Acesso em: 23 set. 2010.

MIDLEJ, Moema M. B. Cartibani. Territorialidade da Universidade Estadual de Santa Cruz. 2004. 273f. Tese (Doutorado em Educação). Universidade Federal da Bahia. Salvador, 2004.

PILETTI, Nelson. Evolução do currículo do curso secundário no Brasil. Revista da Faculdade de Educação, São Paulo, v. 13, nº. 2, p. 2772, jul./dez. 1987.

PEDRÃO. Fernando Pedrão. Uma justiça atinada. In: SOUZA, Maria Adélia Aparecida. $\mathbf{O}$ mundo do cidadão. Um cidadão do mundo. São Paulo: Hucitec, 1996, pp. 58-61.

RISTOFF, D. I. Universidade em foco - reflexões sobre a educação superior. Florianópolis : Insular, 1999. 
ROMANELLI, Otaíza de Oliveira. História da educação no Brasil (1930-1973). 18. ed. Petrópolis: Vozes, 1996.

SOUZA SANTOS, Boaventura de. Pela mão de Alice: o social e o político na pós-modernidade. São Paulo: Cortez, 1999.

SANTOS, Luiz Carlos dos. Investimento em educação superior: a experiência do estado da Bahia com a atividade universitária. 288f. Tese (Doutorado em Ciências Empresariais). Universidade do Museu Social Argentino. 2000.

SANTOS, Milton. A cidade como centro de região: definições e métodos de avaliação da centralidade. Salvador: Livraria Progresso, 1959. Disponível em: <http://miltonsantos.com.br/site/wp-content/ uploads/2011/05/miltonsantos_1959.pdf>. Acesso em: 10/4/2011.

- Da totalidade ao lugar. São Paulo: Edusp, 2005.

. Metamorfoses do espaço habitado. São Paulo: Hucitec, 1988.

SILVA, Sylvio Carlos Bandeira de Mello. Geografia aplicada, planejamento e desenvolvimento: raízes em tributo a Milton Santos. In: SOUZA, Maria Adélia Aparecida. 0 mundo do cidadão: um cidadão do mundo. São Paulo: Hucitec, 1996.

. Estudos sobre globalização, território e Bahia. Salvador: EDU-

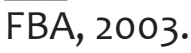

SILVA, Antônia Almeida, PINA, Maria Cristina Dantas. "Educar para enriquecer": o liberal desenvolvimentismo, o projeto tecnocrático e a educação pública na Bahia (1940-1970). Revista HISTEDBR On-line, Campinas, n. 36, p. 57-69, dez. 2009. Disponível em: <http:// www.histedbr.fae.unicamp.br/revista/edicoes/36/art05_36.pdf >. Acesso em: 13 de out. 2010.

SUPERINTENDÊNCIA DE ESTUDOS ECONÔMICOS E SOCIAIS DA BAHIA. Mapas. 1973. Disponível em: <http://www.sei.ba.gov.br>. Acesso em: 22 de julho de 2010.

TEIXEIRA, Anísio. A universidade e a liberdade humana. Revista Brasileira de Estudos Pedagógicos, Rio de Janeiro, v. 20, n. 51, p. 3-22, jul./set. 1953.

. Educação e universidade. Rio de Janeiro: UFRJ, 1998. 